\title{
Inherited and social factors explaining early skills inequality: the case of Chilean children
}

\author{
Ricardo Rivas ${ }^{1}$
}

\begin{abstract}
This article sets out to analyse differences in cognitive and non-cognitive skills between Chilean children. It first examines factors explaining the level of these skills and then goes on to distinguish between children from poor and non-poor households. The data are taken from the first Early Childhood Longitudinal Survey, which was analysed using logistic binary regression. This study finds that variables associated with the mother's intelligence level and other socialization-related variables are statistically significant. However, separate statistical analysis for poor and non-poor households yields different effects of socialization. The main conclusion is that the mother's skills are a relevant explanatory factor in both poor and non-poor children's households. Nonetheless, unequal development of skills in early childhood is not due to inherited traits alone. Stimulation matters in poor households, while the mother's education matters in non-poor households.
\end{abstract}

\section{Keywords}

Children, child development, households, economic conditions, social conditions, poverty, parent education, Chile

\section{JEL classification}

D31, I39, 124

\section{Author}

Ricardo Rivas is a Postdoctoral Researcher with the Centre for the Study of Social Conflict and Cohesion (COES) and the Research Center for Integrated Disaster Risk Management (CIGIDEN), Chile. Email: ricardo.rivas@cigiden.cl.

\footnotetext{
The author is grateful for the insights of anonymous reviewers of this paper. He would also like to thank Dr. Erin Leahey, who provided crucial assistance with the research. He was greatly aided by the comments of colleagues at the Social Inequality Workshop of the School of Sociology and by support from the Writing Skills Improvement Program of the University of Arizona.
} 


\section{Introduction}

Inequality between children challenges the idea of merit. It is not sensible to explain unequal conditions at the beginning of our lives on the basis of individual traits linked to self-determination such as motivation and effort. Different factors operating in the very early stages of life condition future achievements (Baker-Henningham and López, 2010). There is evidence that brain formation critical to the normal development of cognitive and non-cognitive skills takes place between birth and the age of three (Vegas and Santibáñez, 2010). The present study focuses on the factors explaining unequal development of skills in early childhood.

There has been a significant volume of research into the causes underlying the unequal distribution of early cognitive and non-cognitive skills in developed countries. Prominent studies have considered both genetic aspects (Adkins and Guo, 2008) and different facets of children's social environments (Mayer, 1997). In general, examination of the inequality of intellectual skills between children has turned on the classic nature versus nurture debate with regard to individual achievement (Currie, 2011).

This study looks at the tension between nature and nurture, controlling for other factors relevant to early childhood development in the social and economic realms. These aspects of children's socialization are well worth considering, given the neoliberal regimes that have operated in developing countries over the last three decades. Chile is a good case study in this respect.

There has been previous research into Chilean children and their early skills. Noboa-Hidalgo and Urzúa (2012) demonstrated the importance of early education for cognitive and socioemotional development. Cortázar (2015) found that good results in standardized tests among children in fourth grade could mainly be explained by their past participation in early education programmes. Drawing on the same data used by Cortázar, Coddington, Mistry and Bailey (2014) replicated and tested a socioeconomic status model developed by American scholars to explain children's cognitive abilities. Their findings yielded important information on social factors mediating the effect of material conditions on children's receptive vocabulary. Taking these valuable studies into consideration, the present research raises similar questions. First, do the factors associated with inherited traits and socialization explain the different levels of cognitive and non-cognitive skills in Chilean children? Second, do these factors behave in different ways depending on the socioeconomic status of children's households? Although this paper explores concerns similar to those of the aforementioned studies, it has two distinctive features. First, the dependent variable used is a more holistic measure of children's skills, considering both cognitive and non-cognitive traits. Second, this study does not only take social and material conditions as its independent variables, but also considers an inherited trait, namely the cognitive level of children's mothers.

\section{Literature review and theoretical background}

\section{Inherited aspects of early skills}

Genetics and the social environment are often studied together in the social sciences using an approach known as the gene-environment paradigm. Scholarly research from this perspective seeks to understand the environmental factors that may limit or enable genetic tendencies (Fletcher and Boardman, 2013). Some prominent examples include research that queries the interaction between people's educational level and their body mass (Boardman and others, 2014) and how influential neighbourhood peers can be as regards alcohol consumption (Daw and others, 2013) or cigarette use (Daw and others, 2014), depending on adolescents' genetic characteristics. 
However, there has been a great deal of debate around efforts to explain social inequality by inherited aspects. Social scientists still dismiss genetic aspects when considering social issues (Nisbett and others, 2012) or misconstrue the integration of social science and genomics (Conley and Rauscher, 2013). However, there are two aspects that empirical evidence confirms. First, intelligence is a human characteristic which is influenced by genetics and heritable aspects. Second, how strong the influence of genetic aspects on human behaviour is depends on social circumstances (Nisbett and others, 2012). The present study accepts the scientific consensus that intelligence has genetic elements.

When it comes to the findings regarding inherited traits, variables related to the mother's intelligence are part of one of the testable models in this study, called the heritage model. In this regard, the first hypothesis proposed here is that the heritage model is significant in explaining the level of children's skills, controlling for variables associated with their state of health.

\section{Social aspects of early skills}

Prominent studies have focused on phenomena such as seasonality affecting birth weight (Torche and Corvalan, 2010), natural disasters affecting mothers during pregnancy (Torche and Kleinhaus, 2012) and children's cognitive development at preschool ages (Gómez and Yoshikawa, 2017).

In this regard, there are specific variables that this research has integrated into the socialization model. This is operationalized by considering various indicators. One is the age of the mother, which is associated with undesirable parenting traits such as restrictive language and infrequent learning activities (Jung, Fuller and Galindo, 2012). Another indicator is family structure, which might affect child development (McLanahan, 2009). Other variables stand in for cognitive stimulation characteristics, meaning practices and physical environments that stimulate children. Different theoretical models and methodological approaches have included these as variables affecting child development (Jung, Fuller and Galindo, 2012). Children's stimulation is crucial during the first three years of life, according to neuroscience studies. Even the fetal environment and the mother's behaviour during pregnancy have significant consequences for a child's future development (Henrichs and others, 2011). Finally, there is a third aspect concerning the cultural capital in the child's environment. Following Bourdieu's definition of this type of capital, this is a dimension that might foster competence in socially valued areas of practice (Sallaz and Zavisca, 2007), and it has been operationalized for this study by taking the mother's education level. This variable has proved important in other studies, which have demonstrated that low-educated mothers typically have poorer pregnancy outcomes, fewer cognitive skills and poorer socioemotional and behavioural skills (Doyle and others, 2009). The second hypothesis of this study is that the socialization model is significant because it explains children's skill levels when health-related variables are controlled for.

\section{Risk circumstances as control variables}

According to Sen (1987), people need to exert their self-determination in order to develop their abilities and take advantage of opportunities. However, basic individual circumstances such as health, income and education are a necessary starting point. For Roemer (2000), different circumstances can be seen as advantages or disadvantages insofar as they are not related to individual responsibility or effort. In short, lack of capacity and opportunities beyond individuals' control alter the prospects of success in self-determined pursuits (Mithaug, 1996). As previously mentioned, this specific study uses relevant variables to control for inherited and acquired traits explaining children's early skills. These variables have been defined as risk circumstances potentially affecting their cognitive and non-cognitive development. 
Risk circumstances can be understood as biological and environmental conditions that increase the likelihood of negative developmental outcomes (Liaw and Brooks-Gunn, 1994). Research on child development has highlighted several risk factors that interactively influence the intellectual development of children. A number of leading scholars have given different names to this conditioning process: "cumulative risks" (Sameroff and others, 1993), "risk microsystem" (Ayoub and others, 2009) and "cumulative inequality" (Schafer, Ferraro and Mustillo, 2011).

Risk circumstances are associated with pregnancy, birth and the neonatal period. There is evidence that a stressful environment during the prenatal phase affects children's developmental achievements (Henrichs and others, 2011). Furthermore, going by data from the Panel Study of Income Dynamics (PSID) survey in the United States, Conley and Bennet (2000) found that circumstances arising around the time of birth could have a lasting impact on outcomes measured even 19 years later. Birth weight was taken into account because of its demonstrated consequences for children's life courses (Orchinik and others, 2011). For instance, low birth weight is associated with a 34\% decrease in the probability of graduating from high school (Conley and Bennett, 2000). Another aspect is whether the pregnancy was risky or not from an obstetric perspective. These two aspects are an indirect approach to circumstances associated with the mother's pregnancy, given the available data. Finally, an important risk circumstance is the poverty level of the households children live in. Poverty exerts effects on children's future achievements in different ways (Kim and others, 2013). Poverty as an independent variable is analysed further in the following section.

\section{The effects of nature and nurture depending on the socioeconomic context}

Adkins and Guo (2008) have proposed a way of approaching this genetics-social environment debate. Their contention is that the influence of genetic aspects on an individual's attainment interacts with social elements. Genetic traits have had different levels of influence over the course of human history. Thus, genetic factors may be supposed to have mattered considerably in hunter-gatherer societies. According to Guo and Stearns (2002), there is a difference between the level of genetic potential for intellectual development (in the form of innate and inherited mental ability) and the realization of this potential. The latter is conditioned by the social environment. For instance, it has been claimed that the strength of genetic influence on status outcomes depends on the level of inequality in a society (Adkins and Guo, 2008). Studying cognitive skills and their inherited genetic aspects, Nisbett and others (2012, p. 133) wrote that "it appears reasonable to conclude that the heritability of cognitive ability is attenuated among impoverished children and young adults in the United States".

The second research question addresses the idea that the relationship between nature and nurture (genetics and socialization) might be different depending on material conditions. Accordingly, this phenomenon is observed in the context of poor and non-poor children's households. As mentioned, it is necessary to understand the centrality of this variable in the light of the retrenchment of social welfare in developing countries in the last few decades. Neoliberal regimes and decreasing welfare benefits have boosted the role of income as the main indicator of individual and household well-being (Huber and Stephens, 2012). In the context of early childhood development, income and its social distribution matter (ECLAC, 2010).

Thus, observing the nature versus nurture dyad in different socioeconomic contexts is a way to take account of the unequal material circumstances in which children are raised and develop. Household poverty and its expected undesirable consequences for children are a disadvantage (Fergusson, Horwood and Boden, 2008). The effect of poverty has been demonstrated by other researchers (Kim and others, 2013). Furthermore, early childhood is the most crucial phase in life when it comes to the effects of family income on children's future outcomes (Duncan, Kalil and Ziol-Guest, 2010). The relationship between material deprivation and the emotional aspects of parenting has also been 
investigated. Some research has found that poverty exerts its negative effects through the following: punitiveness (Conger and others, 1994), the level of organization of the household routine (Berry and others, 2016), low levels of support from parents (Hashima and Amato, 1994) and low investment in children's enrichment items and activities (Kaushal, Magnuson and Waldfogel, 2011). Given this theoretical and empirical background, the third hypothesis of this study is that variables nested in both heritage and socialization models have a different statistical significance when the poverty level of a child's household is controlled for.

\section{The Chilean case}

The status of Chile with respect to social inequality is controversial. Chile has attained positive results with macroeconomic indicators over the last two decades. Most notable perhaps is the greater equality of opportunity (Contreras and others, 2012). Furthermore, Chile has demonstrated the fluid social mobility characteristic of industrialized countries (Torche, 2005). On the other hand, it is one of the most unequal countries in Latin America and the most unequal among OECD members with respect to income distribution (UNDP, 2010).

There is evidence that income inequality can be explained by both unequal access to education and low investment in human capital. Unequal educational attainment at the post-secondary level has resulted in unequal monetary returns, explaining the high degree of wage inequality in the country (Contreras and Gallegos, 2011). Regarding human capital, there is evidence that low levels of tax revenue in Chile have restricted the scope of fiscal investment in human capital beyond the provision of schooling for low-income sectors, which has not contributed to the reduction of wage inequality (López and Miller, 2008).

There is evidence that the development of early skills is crucial. Consequently, governments should focus on improving the cognitive skills of populations in general (Hanushek and Wößmann, 2006). This recommendation appears sensible, considering that students in Chile obtain very poor results in international tests such as the Programme for International Student Assessment (PISA) and that the cognitive skills of the Chilean population are generally low, according to the International Adult Literacy Survey (IALS) (Brandt, 2010). Like resources of all kinds, skills are not equally distributed because of sharp differences by social background in the Chilean population (OECD/Statistics Canada, 2011).

In the social policy realm, there are reasons to question the approach to early childhood inequality in Chile. The need for government cash transfers to improve children's household income has been continually asserted by the United Nations. In this regard, Chile is in line with the general Latin American situation of low overall investment in human capital (ECLAC, 2010).

\section{Data}

The data source for this research is the first round of the Early Childhood Longitudinal Survey carried out by the Chilean government in 2010. It was the first national panel study in Chile to cover variables associated with the economic and social conditions of children's households, psychological tests for children, psychological tests for mothers (or primary caregivers) and other contextual variables.

The sampling frame for these data is provided by official records of all Chilean children born between 1 March 2004 and 31 August 2009. Out of a sampling frame of 1,297,822 children, 30,000 were chosen by stratified random sampling. The stratification criteria were birth cohorts (2006, 2007, 2008 and 2009), sex and urban or rural area. Within these strata, each unit was chosen by systematic random sampling. After stratification, the sample included 13,895 children, who were evaluated and 
their respective caregivers surveyed. This sample was then narrowed down to all children who had been evaluated using the Battelle Developmental Inventory Test, which is for children aged from 6 months to 2 years old. Then, given the objectives of this research, it was necessary to discard cases with one or more of the following characteristics: (i) households with twin siblings presenting duplication and more complex issues and (ii) subjects for whom the survey was answered by someone other than the child's biological mother. The latter restriction was decided on because there were questions of importance for the analysis that were put only to biological mothers. The analysis sample comprises 4,695 cases from the first round of the aforementioned longitudinal survey.

\section{Measurement}

The dependent variable is the Battelle test score, which represents children's levels of development of cognitive and non-cognitive skills. In research into status attainment, cognitive and non-cognitive skills might be treated as required resources (using a process of distribution) and a set of explanatory variables. However, cognitive and non-cognitive skills can also be regarded as outcomes resulting from specific circumstances (Contreras and others, 2012), as in the present study.

More practically, children were tested with the Battelle Developmental Inventory Test for children aged from 6 months to 2 years old. Broadly, this test assesses skills related to social, psychomotor, communication and cognitive dimensions and assigns a score to each child (Berls and McEwen, 1999). Experts involved with the survey placed children into three categories by their Battelle test scores: deficient development, normal development and superior development. These categories were then reduced to two: normal-superior $=0(94.72 \%)$ and deficient $=1$. Thus, the dependent variable is a dichotomous variable.

All the independent variables have dummy dichotomous responses $(0=$ no; $1=$ yes). They are responses to behaviours or conditions (i.e. insufficient stimulation activities, mother's Wais score test insufficient, etc.). It is important to describe the level of the mother's intelligence as an independent variable. This was gauged using the Wechsler Adult Intelligence Scale (WAIS) test, which measures human intelligence in a way that takes account of non-intellective factors, among other features (Kaplan and Saccuzzo, 2009). The score for this test (applied to children's natural mothers) serves to identify different levels of intelligence. For the dummy variable used in this case, 0 is a normal or superior level and 1 is a deficient level.

The control variables relate to children's health and also have dummy dichotomous responses. It is important to know some details about the child household poverty measure, which is a control variable for responding to our second research question. Household poverty was measured as an absolute level, with households under the poverty line being considered poor. The poverty line is a specific amount of money (per capita) necessary to consume a minimum level of food and its calories. The amount is established each year, and that for 2009 was taken for this study. The absolute level was used to create a dummy variable where 0 is a non-poor household and 1 is a poor household.

As table 1 shows, each variable is presented for both the heritage and the socialization model. There are also control variables. The table shows the frequency distribution of each indicator across the two categories of the dependent variable.

\section{Strategy of analysis}

The first step was a general diagnosis of the relationship between the independent variables and the outcome. A bivariate analysis was carried out using $\chi^{2}$. This testing is appropriate to the level of measurement of the variables in this investigation. 
The rest of the analysis was carried out to test the hypotheses referred to. The strategy of partitioning effects through causal models was used to test the first and second hypotheses. Given that the dependent variable is dichotomous, a binary logistic regression was run to estimate and test the heritage and socialization models. To ascertain how well the models fitted the data, the Bayesian information criterion $(\mathrm{BIC})$ was used to evaluate the improvement with respect to the full model.

Paul Lazarsfeld's elaboration paradigm was applied to test the third hypothesis. This involves partitioning cases into relevant categories in accordance with a theoretical rationale. All the models are estimated separately, considering children's household poverty levels (poor households and non-poor households). Binary logistic regressions were used as in the previous step.

\section{Results}

\section{Bivariate analysis}

Table 1 shows each independent variable in relation to the dependent dichotomous variable (children with normal or deficient skill levels). The percentages of cases with a positive response (yes $=1$ ) for each specific variable are shown in parentheses. In the next columns, the percentages of children with a normal or deficient level are presented for each independent variable. Significant associations between an independent variable and the dependent one are indicated.

For instance, in the case of the "Mother's numerical skills deficient" variable, $67.38 \%$ of the sample have this characteristic. Of those children with a normal level of skills, $66.76 \%$ have a mother with this characteristic. Of those children with a deficient level of skills, $75.81 \%$ do.

Table 1

Descriptive values and bivariate relationships between independent variables and dependent variables ${ }^{a}$

(Percentages)

\begin{tabular}{|c|c|c|}
\hline \multirow{2}{*}{$\begin{array}{l}\text { Model and variables with positive response } \\
\text { (percentages of population) }\end{array}$} & \multicolumn{2}{|c|}{$\begin{array}{c}\text { Children's skill level } \\
\text { (percentages of cases with a positive response for each variable) }\end{array}$} \\
\hline & Normal & Deficient \\
\hline \multicolumn{3}{|l|}{ Heritage model } \\
\hline Mother's numerical skills deficient $(67.38)^{\star}$ & 66.76 & 75.81 \\
\hline Mother's verbal skills deficient (36.19)* & 34.52 & 58.87 \\
\hline \multicolumn{3}{|l|}{ Socialization model } \\
\hline Insufficient stimulation activities (9.42) & 9.25 & 11.69 \\
\hline Insufficient stimulation environment (23.04) ${ }^{\star \star *}$ & 22.12 & 35.48 \\
\hline Mother is young $(6.66)^{\star \star \star}$ & 6.41 & 10.08 \\
\hline Biological father does not live with child $(31.22)^{\star \star \star}$ & 30.78 & 37.1 \\
\hline Mother did not finish high school $(35.44)^{\star \star \star}$ & 34.31 & 50.81 \\
\hline \multicolumn{3}{|l|}{ Control variables } \\
\hline Child had a low birth weight (6.41) & 6.32 & 7.66 \\
\hline Mother had a high-risk pregnancy (12.43) & 12.37 & 13.31 \\
\hline Poor household $(35.94)^{\star}$ & 35.32 & 44.35 \\
\hline N & 4447 & 248 \\
\hline
\end{tabular}

Source: Prepared by the author, on the basis of data from the Early Childhood Longitudinal Survey, 2010.

a Statistical significance levels: ${ }^{* \star} \mathrm{p}<0.001,{ }^{* \star} \mathrm{p}<0.01$, and ${ }^{\star} \mathrm{p}<0.05$, derived from two-tailed $\chi^{2}$ tests of independent variables. 
In this bivariate analysis, there are significant associations between the dependent variable and most of the specific variables associated with the two models defined for this study. Specifically, in the heritage model, "Mother's numerical skills deficient" and "Mother's verbal skills deficient" have a significant association. In the socialization model, "Insufficient stimulation environment", "Mother is young", "Biological father does not live with child" and "Mother did not finish high school" have a significant association.

\section{Multivariate analysis}

The first research question is what factors explain children's cognitive and non-cognitive skill levels. To address this question, three theoretical models were tested.

Table 2 shows all logistic regressions for the three models mentioned. When all independent variables are regressed on the dependent variable (full model), three variables within it are significant, namely "Insufficient stimulation environment" and "Mother's verbal skills deficient". The model in general is significant at $p<0.05$.

Table 2

Coefficients (standard errors) and odds ratios according to three logistic regression models ${ }^{\mathrm{a}}$

\begin{tabular}{|c|c|c|c|c|c|c|}
\hline \multirow{2}{*}{$\begin{array}{l}\text { Dependent variable: low } \\
\text { skills ( } 1=\text { yes; } 0=\text { no) }\end{array}$} & \multicolumn{2}{|c|}{ Full model } & \multicolumn{2}{|c|}{ Socialization model } & \multicolumn{2}{|c|}{ Heritage model } \\
\hline & $\beta$ & $\mathrm{OR}$ & $\beta$ & OR & $\beta$ & OR \\
\hline Insufficient stimulation environment & $\begin{array}{l}0.42^{\star *} \\
(0.15)\end{array}$ & 1.04 & $\begin{array}{l}0.49^{\star \star} \\
(0.15)\end{array}$ & 1.63 & & \\
\hline Insufficient stimulation activities & $\begin{array}{r}0.04 \\
(0.21)\end{array}$ & 1.04 & $\begin{array}{r}0.05 \\
(0.21)\end{array}$ & 1.05 & & \\
\hline Mother is young & $\begin{array}{r}0.15 \\
(0.24)\end{array}$ & 1.16 & $\begin{array}{r}0.19 \\
(0.24)\end{array}$ & 1.23 & & \\
\hline Biological father does not live with child & $\begin{array}{r}0.29 \\
(0.14)\end{array}$ & 1.33 & $\begin{array}{r}0.27 \\
(0.14)\end{array}$ & 1.31 & & \\
\hline Mother did not finish high school & $\begin{array}{r}0.27 \\
(0.15)\end{array}$ & $\begin{array}{r}1.31 \\
(0.20)\end{array}$ & $\begin{array}{r}0.52^{\star * \star} \\
(0.14)\end{array}$ & 1.68 & & \\
\hline Mother's numerical skills deficient & $\begin{array}{r}0.13 \\
(0.16)\end{array}$ & 1.14 & & & $\begin{array}{r}0.19 \\
(0.16) \\
\end{array}$ & 1.21 \\
\hline Mother's verbal skills deficient & $\begin{array}{r}0.80^{* * *} \\
(0.14)\end{array}$ & 2.23 & & & $\begin{array}{r}0.92^{\star \star \star} \\
(0.14)\end{array}$ & 2.52 \\
\hline Mother had a high-risk pregnancy & $\begin{array}{r}0.08 \\
(0.25)\end{array}$ & 1.08 & $\begin{array}{r}0.11 \\
(0.19)\end{array}$ & 1.11 & $\begin{array}{r}0.05 \\
(0.19)\end{array}$ & 1.05 \\
\hline Child had a low birth weight & $\begin{array}{r}0.07 \\
(0.25)\end{array}$ & 1.07 & $\begin{array}{r}0.12 \\
(0.14)\end{array}$ & 1.13 & $\begin{array}{r}0.13 \\
(0.25)\end{array}$ & 1.14 \\
\hline Poor household & $\begin{array}{r}0.12 \\
(0.14)\end{array}$ & 1.13 & $\begin{array}{r}0.18 \\
(0.14)\end{array}$ & 1.2 & $\begin{array}{r}0.21 \\
(0.14)\end{array}$ & 1.24 \\
\hline Constant & $\begin{array}{l}-3.49 \\
(0.17)\end{array}$ & 0.03 & $\begin{array}{l}-3.12 \\
(0.12)\end{array}$ & 0.04 & $\begin{array}{l}-3.22 \\
(0.15)\end{array}$ & 0.04 \\
\hline Likelihood ratio (LR) $\chi^{2}$ & 80.37 & & 46.07 & & 61.15 & \\
\hline Degrees of freedom & 10 & & 8 & & 5 & \\
\hline Bayesian information criterion & 1.573 & & 19.48 & & -20.18 & \\
\hline Probability $>\chi^{2}$ & 0.00 & & 0.00 & & 0.00 & \\
\hline N & 3620 & & 3620 & & 3620 & \\
\hline
\end{tabular}

Source: Prepared by the author, on the basis of data from the Early Childhood Longitudinal Survey, 2010.

a Statistical significance levels: ${ }^{* \star *} \mathrm{p}<0.001 ;{ }^{* *} \mathrm{p}<0.01 ;{ }^{*} \mathrm{p}<0.05$ (two-tailed tests). Coefficients presented in lieu of log-odds ratios. All constants are significant at $\mathrm{p}<0.01 . \beta=$ coefficient. $\mathrm{OR}=$ odds ratio (change factor). 
Regarding the socialization model, the variables "Insufficient stimulation environment" and "Mother did not finish high school" are significant within it. With respect to the former, this is robust because it is still significant in the full model. The socialization model in general is significant at $p<0.05$.

Within the heritage model, the variable "Mother's verbal skills deficient" is significant, as it is in the full model, indicating that it is a robust significant variable. The model as a whole is significant at $p<0.05$.

The Bayesian information criterion (BIC) was used to estimate the goodness of fit of the three different models. Considering only this criterion, in which a smaller number is better, the heritage model seems best $(\mathrm{BIC}=-20.18)$. Also, although some goodness of fit $\left(\mathrm{LR} \chi^{2}\right)$ is lost relative to the full model (80.37), the heritage model retains the second-highest value of $\operatorname{LR} \chi^{2}(61.15)$.

It is possible to retain the first hypothesis, which states that the heritage model is significant in explaining the level of children's skills when health-related variables are controlled for. The second hypothesis, which states that the socialization model is significant, can be also retained. However, the heritage model fits the data better than the latter.

Since the heritage model can be chosen as the explanatory model, it is worth interpreting its significant coefficient. When child health-related variables are controlled for, a child whose mother's verbal skills are deficient is 3 times $(\mathrm{OR}=2.52)$ as likely on average to have a low level of cognitive and non-cognitive skills than a child whose mother scores well for these skills.

To address the second research question, table 3 does reveal some differences between children living in poor versus non-poor households. In the former type of households, the socialization model is not significant. However, "Insufficient stimulation environment", a variable associated with children's socialization, is significant in the full model. The "Mother's verbal skills deficient" variable is significant in the heritage model, as it is in the full model. This means that, controlling for health-related variables, a poor child whose mother's verbal skills are deficient is 3 times $(\mathrm{OR}=2.61)$ as likely on average to have a low level of cognitive and non-cognitive skills as a child whose mother scores well for these skills.

In the case of children living in non-poor households, all the models are significant. The "Mother did not finish high school" variable is significant in the socialization model, as it is in the full model. It can be predicted that, controlling for health-related variables, a non-poor child whose mother did not finish high school is twice $(\mathrm{OR}=1.95)$ as likely on average to have a low level of cognitive and non-cognitive skills as a child whose mother did complete this level of education. Likewise, the "Mother's verbal skills" variable is significant in the heritage model, as it is in the full model. It can be predicted that, controlling for health-related variables, a non-poor child whose mother's verbal skills are deficient is twice $(O R=2.41)$ as likely on average to have a low level of cognitive and non-cognitive skills as a child whose mother scored well for these skills.

In general, the third hypothesis of this study, which states that variables from both the heritage and socialization models have a different statistical significance when the poverty level of the child's household is controlled for, can be partially accepted. First, the socialization model is significant in non-poor households but not in poor countries. Second, the heritage model is significant for both types of households. However, the "Mother's verbal skills deficient" variable has a greater effect on poor children. 
Table 3

Coefficients (standard errors) and odds ratios according to three logistic regression models for poor and non-poor households ${ }^{a}$

\begin{tabular}{|c|c|c|c|c|c|c|c|c|c|c|c|c|}
\hline \multirow{3}{*}{$\begin{array}{l}\text { Dependent variable: } \\
\text { low skills }(1=\text { yes; } 0=\text { no) }\end{array}$} & \multicolumn{6}{|c|}{ Poor households } & \multicolumn{6}{|c|}{ Non-poor households } \\
\hline & \multicolumn{2}{|c|}{ Full model } & \multicolumn{2}{|c|}{$\begin{array}{l}\text { Socialization } \\
\text { model }\end{array}$} & \multicolumn{2}{|c|}{ Heritage model } & \multicolumn{2}{|c|}{ Full model } & \multicolumn{2}{|c|}{$\begin{array}{l}\text { Socialization } \\
\text { model }\end{array}$} & \multicolumn{2}{|c|}{ Heritage model } \\
\hline & $\beta$ & OR & $\beta$ & OR & $\beta$ & $\mathrm{OR}$ & $\beta$ & $\mathrm{OR}$ & $\beta$ & OR & $\beta$ & $\mathrm{OR}$ \\
\hline $\begin{array}{l}\text { Insufficient stimulation } \\
\text { environment }\end{array}$ & $\begin{array}{l}0.51^{\star} \\
(0.21)\end{array}$ & 1.67 & $\begin{array}{l}0.61^{\star \star} \\
(0.21)\end{array}$ & 1.84 & & & $\begin{array}{r}0.33 \\
(0.21)\end{array}$ & 1.39 & $\begin{array}{r}0.39 \\
(0.21)\end{array}$ & 1.48 & & \\
\hline $\begin{array}{l}\text { Insufficient stimulation } \\
\text { activities }\end{array}$ & $\begin{array}{l}-0.13 \\
(0.33) \\
\end{array}$ & 0.88 & $\begin{array}{l}-0.14 \\
(0.33) \\
\end{array}$ & 0.87 & & & $\begin{array}{r}0.19 \\
(0.28) \\
\end{array}$ & 1.21 & $\begin{array}{r}0.19 \\
(0.28) \\
\end{array}$ & 1.21 & & \\
\hline Mother is young & $\begin{array}{l}-0.29 \\
(0.04)\end{array}$ & 0.75 & $\begin{array}{l}-0.19 \\
(0.42)\end{array}$ & 0.83 & & & $\begin{array}{r}0.36 \\
(0.29)\end{array}$ & 1.43 & $\begin{array}{r}0.38 \\
(0.29)\end{array}$ & 1.46 & & \\
\hline $\begin{array}{l}\text { Biological father does not live } \\
\text { with child }\end{array}$ & $\begin{array}{r}0.20 \\
(0.22) \\
\end{array}$ & 1.22 & $\begin{array}{r}0.10 \\
(0.22) \\
\end{array}$ & 1.11 & & & $\begin{array}{r}0.32 \\
(0.19) \\
\end{array}$ & 1.38 & $\begin{array}{r}0.35 \\
(0.19) \\
\end{array}$ & 1.42 & & \\
\hline $\begin{array}{l}\text { Mother did not finish } \\
\text { high school }\end{array}$ & $\begin{array}{r}0.00 \\
(0.22)\end{array}$ & 1.0 & $\begin{array}{r}0.28 \\
(0.21)\end{array}$ & 1.32 & & & $\begin{array}{l}0.46^{*} \\
(0.20)\end{array}$ & 1.58 & $\begin{array}{r}0.67^{\star \star \star} \\
(0.19)\end{array}$ & 1.95 & & \\
\hline $\begin{array}{l}\text { Mother's numerical skills } \\
\text { deficient }\end{array}$ & $\begin{array}{r}0.27 \\
(0.27)\end{array}$ & 1.31 & & & $\begin{array}{r}0.31 \\
(0.27)\end{array}$ & 1.36 & $\begin{array}{r}0.03 \\
(0.20)\end{array}$ & 1.03 & & & $\begin{array}{r}0.17 \\
(0.19)\end{array}$ & 1.19 \\
\hline Mother's verbal skills deficient & $\begin{array}{r}0.96^{\star \star \star} \\
(0.23)\end{array}$ & 2.61 & & & $\begin{array}{r}0.99^{\star \star \star} \\
(0.22)\end{array}$ & 2.69 & $\begin{aligned} 0.68^{\star \star \star} \\
(0.19)\end{aligned}$ & 1.97 & & & $\begin{array}{r}0.088^{\star \star \star *} \\
(0.18)\end{array}$ & 2.41 \\
\hline $\begin{array}{l}\text { Mother had a } \\
\text { high-risk pregnancy }\end{array}$ & $\begin{array}{r}0.19 \\
(0.28)\end{array}$ & 1.21 & $\begin{array}{r}0.25 \\
(0.27)\end{array}$ & 1.28 & $\begin{array}{r}0.19 \\
(0.27)\end{array}$ & 1.21 & $\begin{array}{l}-0.03 \\
(0.29)\end{array}$ & 0.97 & $\begin{array}{l}-0.03 \\
(0.29)\end{array}$ & 0.97 & $\begin{array}{l}-0.09 \\
(0.29)\end{array}$ & 0.91 \\
\hline Child had a low birth weight & $\begin{array}{l}-0.02 \\
(0.39) \\
\end{array}$ & 0.82 & $\begin{array}{r}0.08 \\
(0.39) \\
\end{array}$ & 1.08 & $\begin{array}{r}0.02 \\
(0.39) \\
\end{array}$ & 1.02 & $\begin{array}{r}0.14 \\
(0.34) \\
\end{array}$ & 1.15 & $\begin{array}{r}0.15 \\
(0.33) \\
\end{array}$ & 1.16 & $\begin{array}{r}0.23 \\
(0.33) \\
\end{array}$ & 1.26 \\
\hline Constant & $\begin{array}{l}-3.40 \\
(0.30)\end{array}$ & 0.03 & $\begin{array}{l}-2.82 \\
(0.19)\end{array}$ & 0.75 & $\begin{array}{l}-3.22 \\
(0.26)\end{array}$ & 0.04 & $\begin{array}{r}-3.5 \\
(0.19) \\
\end{array}$ & 0.03 & $\begin{array}{l}-3.26 \\
(0.15) \\
\end{array}$ & 0.04 & $\begin{array}{r}-3.2 \\
(0.17) \\
\end{array}$ & 0.04 \\
\hline Likelihood ratio $(\mathrm{LR}) \chi^{2}$ & 35.03 & & 12.97 & & 27.73 & & 44.8 & & 31.67 & & 26.72 & \\
\hline Degrees of freedom & 9 & & 7 & & 4 & & 9 & & 7 & & 4 & \\
\hline Bayesian information criterion & 29.5 & & 37.2 & & 0.95 & & 24.9 & & 22.6 & & 4.3 & \\
\hline Probability $>\chi^{2}$ & $0.0^{\star \star *}$ & & 0.07 & & $0.0^{\star \star \star}$ & & $0.0^{\star \star *}$ & & $0.0^{\star \star \star}$ & & $0.0^{\star \star \star}$ & \\
\hline N & 1301 & & 1301 & & 1301 & & 2319 & & 2319 & & 2319 & \\
\hline
\end{tabular}

Source: Prepared by the author, on the basis of data from the Early Childhood Longitudinal Survey, 2010.

a Statistical significance levels: ${ }^{* *} \mathrm{p}<0.001 ;{ }^{* *} \mathrm{p}<0.01 ;{ }^{*} \mathrm{p}<0.05$ (two-tailed tests). Coefficients presented in lieu of log-odds ratios. All constants are significant at $\mathrm{p}<0.01 . \beta=$ coefficient. $\mathrm{OR}=$ odds ratio (change factor).

\section{Discussion and conclusion}

Previous researchers have explored social aspects of children's development and found that early education and quality of care matter in their own right (Cortázar, 2015) and mediate other phenomena such as household organization (Berry and others, 2016). This study explores similar concerns and aims to address two main questions. The first concerns the factors explaining inequality between children with respect to their early skills. The second is whether the effects exerted by these factors differ between poor and non-poor children's households.

However, this study has some particular features, focusing as it does on a very early stage of childhood in a developing country using direct measures of children's and their mothers' abilities. In addition, these measures do not concentrate solely on children's cognitive traits since, as other scholars have contended, non-cognitive traits matter as much as cognitive ones in their effects on children's future achievements (Davies and others, 2016).

The findings of this study support the association of both inherited and social aspects with children's early abilities. Among these aspects, poverty emerges as a variable in children's development. However, further analysis was necessary to control for a number of other theoretically relevant variables. 
It has been confirmed that intelligence is genetically conditioned. Mothers' verbal skills explain the skill levels of their children. This is a factor that has been shown to be very robust when different variables are controlled for. A clue to the mechanisms producing this effect is provided by the results of the research carried out by Leyva and Smith (2016), who find that low-income Chilean parents' narrative styles in conversations about negative experiences exert a significant effect on the readiness skills of their children (Leyva and Smith, 2016).

Although socialization-related variables have a lesser explanatory effect, aspects like stimulation and the mother's educational level are relevant in explaining the development of children's skills. However, it needs to be borne in mind that the mother's educational level and verbal cognitive skills are correlated, as Ayoub and others (2009) found. It will be for future research to establish the role of the mother's educational level as part of a causal model incorporating variables similar to those used in this study. Previous research has furnished some ideas. For instance, a nation's development level directly affects mothers' educational level, which in turn affects children's cognitive development (Sun and others, 2016).

When the aforementioned factors are observed, with the distinction made between poor and non-poor households, there are other aspects to take into account. The mother's skills are a relevant explanatory factor in both poor and non-poor children's households, having a greater explanatory effect in poor households. But it is not possible to state that unequal development of early childhood skills in Chile is due only to inherited traits. The tension between nature and nurture is present in poor and non-poor households, but in different ways. Besides the mother's level of intelligence, stimulation matters in poor households, while the mother's education matters in non-poor households.

This research supports the idea that genetics affects an individual's attainments in the short term, in conjunction with aspects of the social environment. Poverty is not only a very difficult condition to reverse: it is also a situation that impedes efforts to break the intergenerational transmission of inequality. It is a cause for concern if the availability and quality of public services such as early education depend on families' purchasing power. Poor children urgently need stimulating environments, which can mitigate genetic conditioning.

Poverty is evidently an impediment to equality of opportunities for children from a very early stage in life. Poor children are less likely to be able to compensate for inherited traits and develop the basic skills needed to interrupt the transmission of factors that reproduce social inequality. They need suitable conditions, which are very difficult to secure under the stress caused by material deprivation, in order to have early stimulation. This point connects the present study to other research that examines the effects of early education on children's development.

It is important to emphasize that the findings of this study, focused as it is on young children, run counter to the claim that children's prospects of thriving in life or achieving acceptable levels of social mobility are only a matter of merit. Advocates of merit as the main explanation for the level of inequality in Chile and other similar societies should embrace these facts and consider that it is not possible to analyse inequality of outcomes (i.e. income) without analysing inequality of conditions (i.e. early skills). This study provides evidence that should help lead the debate in that direction.

Two important limitations of this study concern the data available. First, the survey used for it does not yield any variables relating to the social environment beyond the household. This is an important limitation because other scholars have demonstrated that neighbourhood poverty variables significantly affect children's development (McCoy and others, 2015). However, this limitation is a springboard for future research, which should extend the social environment concept and look for indicators related to public goods and social welfare. Second, early social circumstances, known as in utero conditions (i.e. the parents' relationship, emotional support for the mother, exposure to stressful events, etc.), could not be observed further. Using birth weight and the riskiness of pregnancies as control variables was an indirect way of approaching this important period in children's development. Unfortunately, a 
number of other variables were not part of the survey or were not presented in a suitable form. It is important to mention this limitation because there is enough evidence to show that this period of human development should be integrated into causal analyses of social inequality.

In conclusion, this research provides evidence that both inherited traits and socialization factors are explanatory features of the intergenerational transmission of inequality in Chile that are unrelated to self-determination traits, challenging merit as an explanation of social inequality in the first instance.

\section{Bibliography}

Adkins, D. and G. Guo (2008), "Societal development and the shifting influence of the genome on status attainment", Research in Social Stratification and Mobility, vol. 26, No. 3, Amsterdam, Elsevier.

Alon, S. and M. Tienda (2007), "Diversity, opportunity, and the shifting meritocracy in higher education", American Sociological Review, vol. 72, No. 4, Thousand Oaks, SAGE.

Ayoub, C. and others (2009), "Cognitive skill performance among young children living in poverty: risk, change, and the promotive effects of early head start", Early Childhood Research Quarterly, vol. 24, No. 3, Amsterdam, Elsevier.

Baker-Henningham, H. and F. López (2010), "Early childhood stimulation interventions in developing countries: a comprehensive literature review", IDB Working Paper, No. 213, Washington, D.C., Inter-American Development Bank (IDB).

Berls, A. and I. McEwen (1999), "Battelle developmental inventory", Physical Therapy, vol. 79, No. 8, American Physical Therapy Association.

Berry, D. and others (2016), "Household chaos and children's cognitive and socio-emotional development in early childhood: does childcare play a buffering role?", Early Childhood Research Quarterly, vol. 34, Amsterdam, Elsevier.

Boardman, J. and others (2014), "Is the gene-environment interaction paradigm relevant to genome-wide studies? The case of education and body mass index", Demography, vol. 51, No. 1, New York, Springer.

Boudon, R. (ed.) (1993), Paul F. Lazarsfeld: On Social Research and Its Language, Chicago, University of Chicago Press.

(1974), Education, Opportunity, and Social Inequality: Changing Prospects in Western Society, New York, Wiley.

Brandt, N. (2010), "Chile: climbing on giants' shoulders: better schools for all Chilean children”, OECD Working Paper, No. 784, Paris, Organization for Economic Cooperation and Development (OECD).

Burger, K. (2010), "How does early childhood care and education affect cognitive development? An international review of the effects of early interventions for children from different social backgrounds", Early Childhood Research Quarterly, vol. 25, No. 2, Amsterdam, Elsevier.

Coddington, C., R. Mistry and A. Bailey (2014), "Socioeconomic status and receptive vocabulary development: replication of the parental investment model with Chilean preschoolers and their families", Early Childhood Research Quarterly, vol. 29, No. 4, Amsterdam, Elsevier.

Conger, R. and others (1994), "Economic stress, coercive family process, and developmental problems of adolescents", Child Development, vol. 65, No. 2, Hoboken, Wiley.

(1992), "A family process model of economic hardship and adjustment of early adolescent boys", Child Development, vol. 63, No. 3, Hoboken, Wiley.

Conley, D. (2009), "The promise and challenges of incorporating genetic data into longitudinal social science surveys and research", Biodemography and Social Biology, vol. 55, No. 2, Abingdon, Taylor \& Francis.

Conley, D. and N. Bennett (2000), "Is biology destiny? Birth weight and life chances", American Sociological Review, vol. 65, No. 3, Thousand Oaks, SAGE.

Conley, D. and E. Rauscher (2013), "Genetic interactions with prenatal social environment: effects on academic and behavioral outcomes", Journal of Health and Social Behavior, vol. 54, No. 1, Thousand Oaks, SAGE.

Contreras, D. and others (2012), "The evolution of opportunities for Children in Chile, 1990-2006", CEPAL Review, No. 106 (LC/G.2518-P), Santiago, Economic Commission for Latin America and the Caribbean (ECLAC).

Contreras, D. and S. Gallegos (2011), "Wage inequality in Latin America: a decade of changes", CEPAL Review, No. 103 (LC/G.2487-P), Santiago, Economic Commission for Latin America and the Caribbean (ECLAC).

Cortázar, A. (2015), "Long-term effects of public early childhood education on academic achievement in Chile", Early Childhood Research Quarterly, vol. 32, Amsterdam, Elsevier. 
Currie, J. (2011), "Inequality at birth: some causes and consequences", American Economic Review, vol. 101, No. 3, Nashville, Tennessee, American Economic Association.

Davies, S. and others (2016), "Using the early development instrument to examine cognitive and non-cognitive school readiness and elementary student achievement", Early Childhood Research Quarterly, vol. 35, Amsterdam, Elsevier.

Davis-Kean, P. (2005), "The influence of parent education and family income on child achievement: the indirect role of parental expectations and the home environment”, Journal of Family Psychology, vol. 19, No. 2, Washington, D.C., American Psychological Association.

Daw, J. and others (2014), "The interactive effect of neighborhood peer cigarette use and 5HTTLPR genotype on individual cigarette use", Addictive Behaviors, vol. 39, No. 12, Amsterdam, Elsevier.

(2013), "Genetic sensitivity to peer behaviors: 5HTTLPR, smoking, and alcohol consumption", Journal of Health and Social Behavior, vol. 54, No. 1, New York, SAGE.

Dodge, K., G. Pettit and J. Bates (1994), "Socialization mediators of the relation between socioeconomic status and child conduct problems", Child Development, vol. 65, No. 2, Hoboken, Wiley.

Doyle, O. and others (2009), "Investing in early human development: timing and economic efficiency", Economics \& Human Biology, vol. 7, No. 1, Amsterdam, Elsevier.

Duncan, G., A. Kalil and K. Ziol-Guest (2010), "Early-childhood poverty and adult attainment, behavior, and health", Child Development, vol. 81, No. 1, Hoboken, Wiley.

ECLAC (Economic Commission for Latin America and the Caribbean) (2010), Time for Equality. Closing Gaps, Opening Trails (LC/G.2432(SES.33/3)), Santiago.

Feinstein, L. (2003), "Inequality in the early cognitive development of British children in the 1970 cohort", Economica, vol. 70, No. 277, Hoboken, Wiley.

Fergusson, D., L. Horwood and J. Boden (2008), "The transmission of social inequality: examination of the linkages between family socioeconomic status in childhood and educational achievement in young adulthood", Research in Social Stratification and Mobility, vol. 26, No. 3, Amsterdam, Elsevier.

Filgueira, C. and F. Filgueira (2002), "Models of welfare and models of capitalism: the limits of transferability", Models of Capitalism: Lessons for Latin America, E. Huber (ed.), University Park, Pennsylvania, Pennsylvania State University Press.

Fischer, C. and others (1996), Inequality by Design: Cracking the Bell Curve Myth, New Jersey, Princeton University Press.

Fletcher, J. and J. Boardman (2013), "Integrating work from genetics and the social sciences: an introduction", Biodemography and Social Biology, vol. 59, No. 1, Abingdon, Taylor \& Francis.

Freese, J. (2008), "Genetics and the social science explanation of individual outcomes", American Journal of Sociology, vol. 114, No. 1, Chicago, University of Chicago Press.

Gómez, C. and H. Yoshikawa (2017), "Earthquake effects: estimating the relationship between exposure to the 2010 Chilean earthquake and preschool children's early cognitive and executive function skills", Early Childhood Research Quarterly, vol. 38, Amsterdam, Elsevier.

Guo, G. (2005), "Twin studies: what can they tell us about nature and nurture?", Contexts, vol. 4, No. 3, Thousand Oaks, SAGE.

Guo, G. and K. Harris (2000), "The mechanisms mediating the effects of poverty on children's intellectual development”, Demography, vol. 37, No. 4, New York, Springer.

Guo, G. and E. Stearns (2002), "The social influences on the realization of genetic potential for intellectual development”, Social Forces, vol. 80, No. 3, Oxford, Oxford University Press.

Hanushek, E. and L. Wößmann (2006), "Does educational tracking affect performance and inequality? Differencesin-differences evidence across countries", The Economic Journal, vol. 116, No. 510, Hoboken, Wiley.

Hashima, P. and P. Amato (1994), "Poverty, social support, and parental behavior", Child Development, vol. 65, No. 2, Hoboken, Wiley.

Hauser, R. (2002), "Meritocracy, cognitive ability and the sources of occupational success", CDA Working Paper, No. 98-07, Madison, University of Wisconsin.

Henrichs, J. and others (2011), "Parental family stress during pregnancy and cognitive functioning in early childhood: the generation R study", Early Childhood Research Quarterly, vol. 26, No. 3, Amsterdam, Elsevier.

Herrnstein, R. and C. Murray (1994), The Bell Curve, New York, Free Press.

Huber, E. and J. Stephens (2012), Democracy and the Left: Social Policy and Inequality in Latin America, Chicago, University of Chicago Press.

Huston, A., V. McLoyd and C. García (1994), "Children and poverty: issues in contemporary research", Child Development, vol. 65, No. 2, Hoboken, Wiley. 
Jefferis, B., C. Power and C. Hertzman (2002), "Birth weight, childhood socioeconomic environment, and cognitive development in the 1958 British birth cohort study", BMJ, vol. 325, London, The British Medical Journal.

Jung, S., B. Fuller and C. Galindo (2012), "Family functioning and early learning practices in immigrant homes", Child Development, vol. 83, No. 5, Hoboken, Wiley.

Kaplan, R. and D. Saccuzzo (2009), Psychological Testing. Principles, Applications, and Issues, Belmont, Cengage Learning.

Karoly, L., M. Kilburn and J. Cannon (2005), Early Childhood Interventions: Proven Results, Future Promise, Santa Monica, Rand.

Kaushal, N., K. Magnuson and J. Waldfogel (2011), "How is family income related to investments in children's learning?", Whither Opportunity? Rising Inequality, Schools, and Children's Life Chances, G. Duncan and R. Murnane (eds.), New York, Russell Sage Foundation/Spender Foundation.

Kim, P. and others (2013), "Effects of childhood poverty and chronic stress on emotion regulatory brain function in adulthood", Proceedings of the National Academy of Sciences of the United States of America, vol. 110, No. 46, Washington, D.C., National Academy of Sciences of the United States of America.

Klebanov, P. and others (1998), "The contribution of neighborhood and family income to developmental test scores over the first three years of life", Child Development, vol. 69, No. 5, Hoboken, Wiley.

Kohn, M. (1999), "Two visions of the relationship between social structure and personality: the 'bell curve' versus social structure and personality", A Nation Divided: Diversity, Inequality and Community in American Society, P. Moen, D. Dempster and H. Walker (eds.), Ithaca, Cornell University Press.

Lareau, A. (2002), "Invisible inequality: social class and childrearing in black families and white families", American Sociological Review, vol. 67, No. 5, Thousand Oaks, SAGE.

Leyva, D. and M. Smith (2016), "Beyond book reading: narrative participation styles in family reminiscing predict children's print knowledge in low-income Chilean families", Early Childhood Research Quarterly, vol. 37, Amsterdam, Elsevier.

Liaw, F. and J. Brooks-Gunn (1994), "Cumulative familial risks and low-birthweight children's cognitive and behavioral development", Journal of Clinical Child Psychology, vol. 23, No. 4, Abingdon, Taylor and Francis.

Lichter, D. (1997), "Poverty and inequality among children”, Annual Review of Sociology, vol. 23, Annual Reviews.

López, R. and S. Miller (2008), "Chile: the unbearable burden of inequality", World Development, vol. 36, No. 12, Amsterdam, Elsevier.

Mayer, S. (1997), What Money can't Buy: Family Income and Children's Life Chances, Cambridge, Massachusetts, Harvard University Press.

McCoy, D. and others (2015), "Neighborhood economic disadvantage and children's cognitive and socialemotional development: exploring Head Start classroom quality as a mediating mechanism", Early Childhood Research Quarterly, vol. 32, Amsterdam, Elsevier.

McLanahan, S. (2009), "Fragile families and the reproduction of poverty", The Annals of the American Academy of Political and Social Science, vol. 621, No. 1, Thousand Oaks, SAGE.

McLanahan, S. and C. Percheski (2008), "Family structure and the reproduction of inequalities", Annual Review of Sociology, vol. 34, Annual Reviews.

McNamee, S. and R. Miller (2009), The Meritocracy Myth, Lanham, Maryland, Rowman \& Littlefield.

Mithaug, D. (1996), Equal Opportunity Theory, Thousand Oaks, SAGE.

Moloney, M. (2005), "The Starting Gate: Birth Weight and Life Chances by Dalton Conley, Kate W. Strully, Neil G. Bennett; Conceiving Risk, Bearing Responsibility: Fetal Alcohol Syndrome and the Diagnosis of Moral Disorder by Elizabeth M. Armstrong", Social Forces, vol. 83, No. 4, Oxford, Oxford University Press.

Nisbett, R. and others (2012), "Intelligence: new findings and theoretical developments", American Psychologist, vol. 67, No. 2, Washington, D.C., American Psychological Association.

Noboa-Hidalgo, G. and S. Urzúa (2012), "The effects of participation in public child care centers: evidence from Chile", Journal of Human Capital, vol. 6, No. 1, Chicago, Chicago University Press.

OECD (Organization for Economic Cooperation and Development/Statistics Canada) (2011), Literacy for Life: Further Results from the Adult Literacy and Life Skills Survey, Paris, OECD Publishing.

Orchinik, L. and others (2011), "Cognitive outcomes for extremely preterm/extremely low birth weight children in kindergarten", Journal of the International Neuropsychological Society, vol. 17, No. 6, Cambridge, Cambridge University Press.

Osborne, C. and S. McLanahan (2007), "Partnership instability and child well-being", Journal of Marriage and Family, vol. 69, No. 4, Hoboken, Wiley. 
Padua, J. (2006), "Infancia y educación", Convergencia, No. 40, Toluca, Autonomous University of the State of Mexico.

Roemer, J. (2000), "Equality of opportunity", Meritocracy and Economic Inequality, K. Arrow, S. Bowles and S. Durlaf (eds.), New Jersey, Princeton University Press.

Ruzek, E. and others (2014), "The quality of toddler child care and cognitive skills at 24 months: propensity score analysis results from the ECLS-B", Early Childhood Research Quarterly, vol. 29, No. 1, Amsterdam, Elsevier.

Sallaz, J. and J. Zavisca (2007), "Bourdieu in American sociology, 1980-2004", Annual Review of Sociology, vol. 33, Annual Reviews.

Sameroff, A. (1986), "Environmental context of child development", The Journal of Pediatrics, vol. 109, No. 1, Amsterdam, Elsevier.

Sameroff, A. and others (1993), "Stability of intelligence from preschool to adolescence: the influence of social and family risk factors", Child Development, vol. 64, No. 1, Hoboken, Wiley.

(1987), "Intelligence quotient scores of 4-year-old children: social-environmental risk factors", Pediatrics, vol. 79, No. 3, Itasca, American Academy of Pediatrics.

Schafer, M., K. Ferraro and S. Mustillo (2011), "Children of misfortune: early adversity and cumulative inequality in perceived life trajectories", American Journal of Sociology, vol. 116, No. 4, Chicago, Chicago University Press.

Sen, A. (1987), Commodities and Capabilities, New Delhi, Oxford University Press.

Sun, J. and others (2016), "Factors related to parents' engagement in cognitive and socio-emotional caregiving in developing countries: results from multiple indicator cluster survey 3", Early Childhood Research Quarterly, vol. 36, Amsterdam, Elsevier.

Torche, F. (2005), "Unequal but fluid: social mobility in Chile in comparative perspective", American Sociological Review, Thousand Oaks, SAGE, vol. 70, No. 3.

- (2011), "The effect of maternal stress on birth outcomes: exploiting a natural experiment", Demography, vol. 48, No. 4, New York, Springer.

Torche, F. and A. Corvalán (2010), "Seasonality of birth weight in Chile: environmental and socioeconomic factors", Annals of Epidemiology, vol. 20, No. 11.

Torche, F. and K. Kleinhaus (2012), "Prenatal stress, gestational age and secondary sex ratio: the sex-specific effects of exposure to a natural disaster in early pregnancy", Human Reproduction, vol. 27, No. 2, Oxford, Oxford University Press.

UNDP (United Nations Development Programme) (2010), Regional Human Development Report for Latin America and the Caribbean 2010. Acting on the future: breaking the intergenerational transmission of inequality, San José.

Vegas, E. and L. Santibáñez (2010), The promise of early childhood development in Latin America and the Caribbean, Washington, D.C., World Bank/Mayol.

Wagmiller, R. and others (2006), "The dynamics of economic disadvantage and children's life chances", American Sociological Review, vol. 71, No. 5, Thousand Oaks, SAGE.

Warren, R. (2015), "What do growing childhood socioeconomic inequalities mean for the future of inequalities in adult health?", Minneapolis, University of Minnesota [online] http://www.rob-warren.com/uploa ds/4/5/1/2/45120697/2015.05.28_paper.pdf. 